\title{
Correction to: Evaluation of medicinal plants from Central Kalimantan for antimelanogenesis
}

\author{
Enos Tangke Arung ${ }^{1,2} \cdot$ Irawan Wijaya Kusuma ${ }^{2} \cdot$ Eva Oktoberyani Christy $^{3} \cdot$ Kuniyoshi Shimizu $^{1} \cdot$ Ryuichiro Kondo $^{1}$
}

Published online: 25 February 2022

(c) The Author(s) under exclusive licence to The Japanese Society of Pharmacognosy 2022

Correction to: J Nat Med (2009) 63:473-480

https://doi.org/10.1007/s11418-009-0351-7

In the original publication of the article, third author name was published incorrectly as "Eva Oktoberiani Christy". The correct name should read as "Eva Oktoberyani Christy".

Publisher's Note Springer Nature remains neutral with regard to jurisdictional claims in published maps and institutional affiliations.

The original article can be found online at https://doi.org/10.1007/ s11418-009-0351-7.

Kuniyoshi Shimizu

shimizu@agr.kyushu-u.ac.jp

1 Department of Forest and Forest Products Sciences, Faculty of Agriculture, Kyushu University, 6-10-1 Hakozaki,

Higashi-ku, Fukuoka 812-8581, Japan

2 Department of Forest Product Technology, Faculty of Forestry, Mulawarman University, Samarinda 75123, Indonesia

3 Department of Forest Product, Faculty of Agriculture, Palangkaraya University, Palangkaraya 73112, Indonesia 